\title{
Alternative pretreatments of rice and tobacco wastes for the production of fermentable sugars
}

\section{Pretratamientos alternativos de residuos de arroz y tabaco para la obtención de azúcares} fermentables

\author{
C. Curbelo-Hernández (101*, E. Véliz-Lorenzo² ${ }^{2}$ José Ma. Ameneiros Martínez (ib) \\ ${ }^{1}$ Facultad de Ingeniería Química, Universidad Tecnológica de La Habana "José Antonio Echeverría" (Cujae). Calle 114 e/ Rotonda y \\ Ciclovía. 11901. C. P 19390. La Habana, Cuba. \\ 2Dirección de Medioambiente, Centro Nacional de Investigaciones Científicas (CNIC). Calle 25 y 158, \# 15202. C. P. 12100. La Habana, \\ Cuba.
}

\author{
ARTICLE INFO: \\ Received: September 05, \\ 2017 \\ Accepted: February 19, \\ 2019
}

\section{AVAILABLE ONLINE:}

April 22, 2019

\section{KEYWORDS:}

Bioethanol, lignocellulosic wastes, ultrasound, ozone

Bioetanol, residuos lignocelulósicos, ultrasonido, ozono

\begin{abstract}
The scarce oil supplies and the emissions of gases of greenhouse effect have caused the interest in production and utilization of lignocellulosic bioethanol. This can substitute partially or totally the fossil fuels. The stages of pretreatment and enzymatic hydrolysis are the most expensive. Different pretreatments have been studied for ethanol production from these materials. Their results depend on the method characteristics and on biomass used. The agroindustrial wastes present a composition with possibilities of being evaluated like raw material for bioethanol production. In the present research, the pretreatment stages with Ultrasound and Ozone are studied, in order to decrease the lignin content and to increase the performance of the fermentative sugars in the lignocellulosic wastes (rice hull and dark tobacco vein). In the first pretreatment procedure, time and waste type were studied and in the second stage, the ozone concentration, waste type and moisture content were the studied variables. A combined procedure was applied to the best preliminary results. It is demonstrated that a decrease in the lignin concentration and the structural transformation of the materials under consideration come true. The best results were gotten for the rice hulls.
\end{abstract}

RESUMEN: Las escasas reservas de petróleo y las emisiones de gases de efecto invernadero han dado lugar al interés en la producción y utilización de bioetanol lignocelulósico. Éste puede sustituir de forma parcial o total a los combustibles fósiles. Las etapas de pretratamiento e hidrólisis enzimática son las más costosas. Se han estudiado diferentes pretratamientos para la producción de etanol a partir de estos materiales, cuyos resultados dependen de las características del método y de la biomasa empleada. Los residuales agroindustriales presentan una composición con posibilidades de ser evaluados como materia prima para la obtención de bioetanol. En la presente investigación se estudia la etapa de pretratamiento con Ultrasonido y Ozono, para disminuir el contenido de lignina y aumentar el rendimiento de los azúcares fermentables en los residuos (cáscara de arroz y vena de tabaco negrol. En el primer pretratamiento, se estudiaron como factores el tiempo y tipo de residual y en la ozonólisis, la concentración de ozono, tipo de residual y humedad. Para los mejores resultados obtenidos en cada pretratamiento, se realiza un procedimiento combinado, demostrándose una disminución en la concentración de lignina y la transformación estructural de los materiales en estudio. La cáscara de arroz muestra los mejores resultados.

\section{Introduction}

The increments of the price of oil and the uncertainty on its stable supply, along with the deterioration of the environment, have caused an increasing interest about biofuels in the search of new energetic sources. Many research projects are developed in order to carry

E-mail: caryđquimica.cujae.edu.cu

ISSN 0120-6230

e-ISSN 2422-2844 
out ethanol production from lignocellulosic biomass at commercial scale. Wood and forest wastes, recycled paper, residues of the pulp and paper industries as well as urban solid wastes are the most studied materials.

The bioethanol is one of the most usedrenewable energy source at present. Its advantages, from the environmental point of view, are recognized [1]. The hydrolysis of cellulose and hemicellulose contained in some lignocellulosic materials, such as municipal solid wastes and yard wastes, is one of the ways to produce ethanol. The generation of large volumes of agricultural and industrial residues and their necessary treatment, as well as their availability and low costs, put forward the potentiality of being used as raw material for bioethanol production.

The process of enzymatic conversion from the cellulosic components to fermentable sugars is very well studied at current times, due to its advantages and possibilities of being improved. The main technological and cost-reducing obstacles that limit the obtaining of bioethanol through an enzymatic processare the low digestibility of lignocellulosic materials and the high price of enzymes. Additionally, the factors that affect the susceptibility to the enzymatic attack include the crystalline characteristics of cellulose, protection exerted by hemicellulose and lignin and, in less measure, the accessible surface of cellulose and the degree of acetylation of the hemicellulose [2].

The physical pretreatments can increase the superficial area and the size of the pores. This effect promotes the decrement of crystalline characteristics and polymerization degree of cellulose to improve enzymatic hydrolysis of lignocellulosic materials. These methods can use high temperatures and pressures, milling, radiation or freezing, all of them require a high-energy consumption (Figure 1).

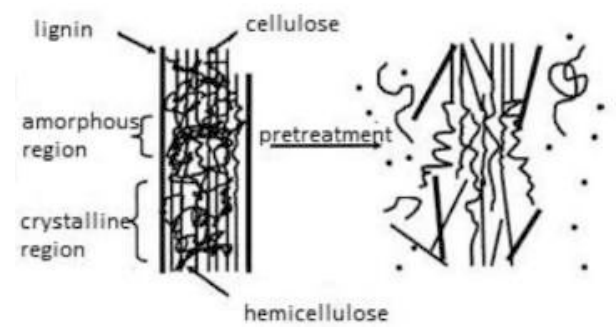

Figure 1 Effect of the pretreatment on the biomass. Source: Rodríguez (2013) [3]

However, unlike the chemical methods, they do not use chemical reagents neither to break off the crystalline structure of the material nor to neutralize acid or basic effluents. They do not demand expensive construction materials in the facilities, neither the elimination of formed salts when neutralizing, nor the removal of toxic products for the subsequent stages of enzymatic hydrolysis and fermentation.

Ultrasound is one of the most commonly applied physical pretreatment. It can be defined as a high frequency wave that cannot be heard by the human beings. Waves of pressure are transmitted through the intervening midway and its main advantage is that the necessary energy is directly related to the physical effects of the acoustic cavitation. Sound waves can break the forces of cohesion in a liquid and create micro-cavities, because of micro-bubbles growing up until the moment they become unstable, in response to the sound waves. Bubbles collapse violently, creating drastic conditions inside the midway during an extremely short time [4]. The ultrasound has been used for helping hemicellulose extraction, cellulose and lignin from of the lignocellulosic biomass, like the rice hull and corn and wheat straws, using watery alkaline or neutral solutions [5].

Chemical pretreatments include acid treatments, alkalis, solvents or ammonia and the ozone breaking. This last one allows degrading effectively the lignin and a portion of hemicellulose, since ozone is highly reactive in front of compounds with functional groups with electronic high density, like in the lignin case. Ozone attacks lignin and free soluble compounds of small molar mass, principally organic acids like formic acid or the acetic one, which can reduce the $\mathrm{pH}$ from 6.5 to 2 . In spite of that, this method proves to be attractive for several investigators, because they allege the production of toxic substances in quantities that do not interfere with upper enzymatic hydrolysis and fermentation [6].

In developing countries, including those in Latin America and the Caribbean (LAC), biofuels are a way of addressing a broader set of policy objectives, ranging from energy security to improvements in balance-of-payments performance, rural development, export promotion and meeting environmental objectives [7].

With the current scenario of waste generation from a wide variety of sources, and its inadequate disposal, various methods to convert it into useful products in the shortest possible time are being studied. Various options for the use and recycling of lignocellulosic waste generated in agroindustries have been described. Waste from the wine industry, for example, is used to obtain tartrates. Residues from Maguey tequila bagasse processes have been used for the production of seedlings, biopolymers, enzymes and other metabolites. Sugarcane bagasse has been bioprocessed to obtain cattle food. 
Table 1 Lignocellulosic composition of studied materials

\begin{tabular}{lccc}
\hline Wastes & $\begin{array}{c}\text { Cellulose } \\
(\%)\end{array}$ & $\begin{array}{c}\text { Hemicellulose } \\
(\%)\end{array}$ & $\begin{array}{c}\text { Lignin } \\
(\%)\end{array}$ \\
\hline Rice hull & $28.50 \pm 1.80$ & $23.50 \pm 1.95$ & $22.00 \pm 1.95$ \\
Dark tobacco vein & $25.96 \pm 2.55$ & $38.73 \pm 2.40$ & $4.90 \pm 0.70$ \\
\hline
\end{tabular}

Other lignocellulosic residues are used as raw material to produce ethanol, for the manufacture of paper and organic acids production, amino acids, vitamins and others [8].

Ultrasound and the ozone are evaluated in this research as pretreatments for agricultural wastes (rice hull and dark tobacco vein) in independent or combined ways, in order to analyze their effects on reducing sugar concentrations as well as the affectation on the structure of these materials.

\section{Experimentation}

\subsection{Conditioning and characterization of the raw material}

Two lignocellulosic wastes were evaluated for this study, considering their availability because they are not used for any other process. Table 1 shows their characteristics.

- Rice hull, supplied for the Grains Research Institute, located at Artemisa Province, Cuba.

- Dark tobacco vein, supplied for Lázaro Peña Company, located at Holguín Province, Cuba.

Sample preparation consisted firstly in material drying at $70^{\circ} \mathrm{C}$ in stove during 24 hours. Later, milling was developed at an electric mill of agate; label Fritschpulverisette, kind 02.102 in order to guarantee a particle size smaller than 1 $\mathrm{mm}$ according literature recommendations [2-4]. A sieve analysis was developed in order to determine the average size of particles (superficial volumetric diameter or Reboux diameter) for each waste. Figure 2 illustrates the scheme of this experimental work.

The following assays were carried out to characterize the raw materials:

- Moisture content: NREL Standard [9].

- Lignin content: NREL Standard [10].

- Ashes: NREL Standard [11].

- Reducing sugars: DNS Method [12].

In order to check the pretreatment effect on the structure of each material, samples were analyzed previously and after being treated. Scanning Electron Microscopy (SEM) was developed in a Microscope JEOL JSM 6,300 at Micro Analysis and Traces Lab (MiTAC) of the University of
Amberes, Belgium, at following conditions: voltage of acceleration of the electrons $20 \mathrm{kV}$, intensity of $1 \mathrm{nA}$, and magnification $\times 50$ and $\times 250$ with a distance of work 0.015 m.

\subsection{Ultrasound pretreatment}

An immersion ultrasonic device label FRITSCH Laborrett with $30 \mathrm{kHz}$ 's frequency was used. It is installed at the Material Technological Lab of the Center of Technological Studies and Nuclear Development (CEADEN) in Havana, Cuba. Two independent variables or factors at two levels were set in order to study this pretreatment, proving to be an experimental design $2^{2}$. Two different response variables were defined: reducing sugar and lignin concentration. Replies were carried out at all experimental points.

A sample of approximately $0.020 \mathrm{~kg}$ is weighted in a previously tared beaker of $250 \mathrm{~mL}$. Deionized water $(200 \mathrm{~mL})$ is added into it at $80^{\circ} \mathrm{C}$. The beaker is after introduced in an ultrasound bath. Used times were 1 and 2 hours according to previous reports [13]. After the appointed time, the content of the beaker is filtrated. Sugar reducing concentration and soluble lignin content are determined. The solid is dried in stove at $105^{\circ} \mathrm{C}$ during 4 hours, afterwards concentration of insoluble lignin is determined.

\subsection{Ozone pretreatment}

This pretreatment was developed in a fixed bed reactor with a diameter of $0.027 \mathrm{~m}$. Lignocellulosic material is submitted to an oxygen-ozone $\left(\mathrm{O}_{3}\right)$. This installation is found in the ozone laboratory of the Environmental Management of the National Scientific Research Center (CNIC, Spanish acronym) in Havana, Cuba. In order to study this pretreatment, three independent variables or factors (moisture waste, concentration of $\mathrm{O}_{3}$ and waste typel were established at two levels, proving to be an experimental design $2^{3}$. The defined response variables were the concentration of reducing sugars and the lignin. Replies were carried out in all the experimental points.

A sample of approximately $0.002 \mathrm{~kg}$ of the residual one is weighted and added into the reactor. A flow of gas of $16 \mathrm{~L} / \mathrm{h}$ is passed through during 2 hours. In order to fix the study variables, the results of García Cubero et al. were taken into account [14]. The ozoneconcentrations were $20 \mathrm{mg} / \mathrm{L}$ and $50 \mathrm{mg} / \mathrm{L}$ and regarding moisture, it was decided to work at the initial moisture content of the sample and at $30 \%$ in dry basis. A certain quantity of water was added to lignocellullosic material. After the ellapse of the established time, the ozonized material is extracted to develop the analytical determinations. 


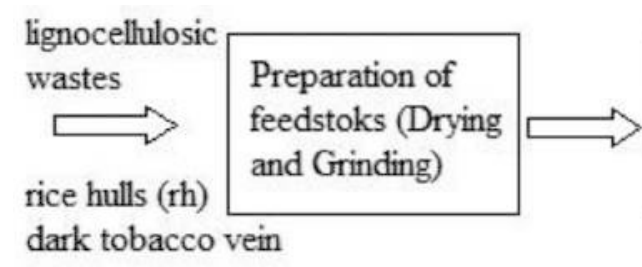

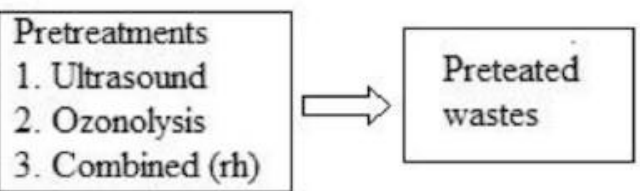

Figure 2 Diagram of pretreatment of lignocellulosic wastes
Finally, with the best conditions obtained for each pretreatment separately, a combined pretreatment with ultrasound - ozone came true with its corresponding replies, according the literature reports [15]. The processing of the experimental results came true by means of the STATGRAPHICS PLUS 5.1.

\section{Results and discussion}

In Table 2, the concentrations of lignin, reducing sugars, moisture, ashes and the average size of particle (dp) of the lignocellulosic wastes are shown. As it is observed, the rice hull presents a superior content of cellulose regarding hemicelluloses contents of $28.50 \%$ and $23.50 \%$, respectively. However, the dark tobacco vein presents a higher content of hemicelluloses (38.73\%) than cellulose (25.96\%). Thehighest difference between these two wastes lives in the content of lignin. This aspect influences in its behavior in front of the two studied pretreatments.

It is important to point out that in all cases the concentration of insoluble lignin was determined as much as soluble, but for this last, their values were very low and for that reason in all Tables the insoluble lignin concentration is reported.

Regarding the content of reducing sugars (lightly superior) and moisture, the tobacco residual presents a higher composition than the rice hull, due to its higher hygroscopicity; however, regarding the ashes, the dark tobacco vein presents lightly lower content than the rice hull. These results correspond with the ones reported by Estrada (2010) [16] for the case of tobacco and for different authors for the rice hull [17].

The milling process applied, guaranteed a material with $0.27 \mathrm{~mm}$ of average size for the rice hull and of 0.21 $\mathrm{mm}$ for the tobacco residual. In both cases, the average particle size was lower than $1 \mathrm{~mm}$, which is in agreement with the reported value. Under these conditions, any used pretreatment can have bigger effectiveness, even for the attack of the enzymes in the process of hydrolysis.

\subsection{Ultrasound pretreatment}

Transformation of the surface structure of the material to improve the enzymatic hydrolysis is what happens when ultrasound is applied. The influence of the studied variables over the concentration of reducing sugars and lignin is reported in Table 3. As it is observed, increasing time for the two residuals, the concentration of reducing sugars increases. This effect is more accented in the behavior of the rice hull. It is considered that the work temperature at $80^{\circ} \mathrm{C}$ originates this result because, at these conditions, the reducing sugars are more soluble than the lignin.

In the case of the lignin, the difference in its concentration for both residuals regarding the time increment does not have the same behavior. If the initial concentration of lignin of each material without any treatment is taken into account, (see Table 2), the ultrasound pretreatment does not contribute to lignin degradation under the studied conditions for both wastes.

The statistical processing of the results for this pretreatment shows that the studied factors have significant influence, for reliability of $95 \%$, on the reducing sugars and only the type of residual in the case of lignin. This corresponds to the qualitative analysis of the previous Table. This behavior isillustrated in Figure 3 and it is associated to the remarkable difference of lignin content in both residuals.

From the obtained results, it can come into question that the ultrasound pretreatment under the studied conditions is not able to degrade lignin, but it does favor the increment of the reducing sugars. This corresponds with Chun Yao Yang et al; results (2012) [13], where they demonstrated the effect of time on the yield of hemicelluloses.

\subsection{Ozone pretreatment}

As it was stated previously, this pretreatment aspires to degrade the lignin, although the hydrolysis of the hemicellulose also is favored. Results are shown below (Table 4).

According to the results shown in table 4, when 
Table 2 Physical and chemical characteristics of lignocellulosic wastes ( $\%$ in dry base weight)

\begin{tabular}{lccccc}
\hline Wastes & $\begin{array}{c}\text { Reducing } \\
\text { sugars (mg/L) }\end{array}$ & Lignin (\%) & Moisture (\%) & $\begin{array}{c}\text { Ashes } \\
\text { (\%) }\end{array}$ & $\begin{array}{c}\text { Average particles } \\
\text { size(mm) }\end{array}$ \\
\hline Rice hull & $4.352 \pm 0.568$ & $22.00 \pm 1.95$ & $10 \pm 0.25$ & $15 \pm 1.02$ & 0.27 \\
Dark tobacco vein & $5.571 \pm 0.346$ & $4.90 \pm 0.70$ & $16 \pm 0.42$ & $13 \pm 0.96$ & 0.21 \\
\hline
\end{tabular}

Table 3 Effect of the studied factors over chemical composition of wastes ( $\%$ in dry base weight)

\begin{tabular}{lccc}
\hline Wastes & $\begin{array}{c}\text { Time } \\
\text { (h) }\end{array}$ & $\begin{array}{c}\text { Reducing sugars } \\
\text { (mg/L) }\end{array}$ & $\begin{array}{c}\text { Lignin } \\
\text { (\%) }\end{array}$ \\
\hline Rice hull & 1 & $9.879 \pm 0.025$ & $20.100 \pm 0.150$ \\
Rice hull & 2 & $16.664 \pm 0.016$ & $19.800 \pm 0.095$ \\
Dark to bacco vein & 1 & $8.131 \pm 0.014$ & $4.500 \pm 0.085$ \\
Dark to bacco vein & 2 & $9.198 \pm 0.085$ & $4.300 \pm 0.076$ \\
Dark to bacco vein & 2 & $9.605 \pm 0.098$ & $4.600 \pm 0.056$ \\
Rice hull & 2 & $16.102 \pm 0.095$ & $20.200 \pm 0.010$ \\
Dark to bacco vein & 1 & $8.295 \pm 0.099$ & $4.700 \pm 0.090$ \\
Rice hull & 1 & $9.060 \pm 0.102$ & $19.900 \pm 0.012$ \\
\hline
\end{tabular}

Table 4 Effect of the studied factors on chemical composition of waste ( $\%$ in dry base weight)

\begin{tabular}{cclcc}
\hline $\begin{array}{c}\text { Moisture } \\
(\%)\end{array}$ & $\begin{array}{c}\mathbf{c}\left(\mathbf{O}_{\mathbf{3}}\right) \\
(\mathbf{m g} / \mathbf{L})\end{array}$ & Wastes & $\begin{array}{c}\text { Reducing sugars } \\
(\mathbf{m g} / \mathbf{L})\end{array}$ & $\begin{array}{c}\text { Lignin } \\
(\%)\end{array}$ \\
\hline 10 & 50 & Rice hull & $9.995 \pm 0.013$ & $17.825 \pm 0.120$ \\
10 & 20 & Rice hull & $8.118 \pm 0.016$ & $19.222 \pm 0.105$ \\
30 & 50 & Rice hull & $13.698 \pm 0.087$ & $15.745 \pm 0.138$ \\
30 & 20 & Dark tobacco vein & $9.999 \pm 0.055$ & $3.800 \pm 0.012$ \\
30 & 20 & Rice hull & $9.643 \pm 0.065$ & $15.920 \pm 0.125$ \\
10 & 20 & Dark tobacco vein & $8.245 \pm 0.036$ & $4.228 \pm 0.034$ \\
30 & 50 & Dark tobacco vein & $10.598 \pm 0.048$ & $3.675 \pm 0.022$ \\
10 & 50 & Dark tobacco vein & $11.687 \pm 0.056$ & $3.356 \pm 0.056$ \\
\hline
\end{tabular}

moisture content of lignocellulosic material increases, the concentration of reducing sugars and degradation of lignin also increase. This does not happen when the ozone concentration increases. This behavior is in accordance to Cubero et al; (2008) [14]. They studied the effect of 5 factors (size of particle, concentration of ozone, flow of gas, waste type, and moisture content), and only the last two proved to be significant, $95 \%$ of reliability. They worked with a flow of $60 \mathrm{~L} / \mathrm{h}$ of gas and degraded the $65 \%$ of the lignin of the studied material. In the present, the gas flow was $16 \mathrm{~L} / \mathrm{h}$, far below the one they used, due to the experimental installation availability. This influenced the low degradation of lignin.

In the case of lignin, the difference in its concentration for the two residuals does not have the same behavior. Once the concentration of initial lignin of each untreated waste was known (see Table 2), it is evident than for both lignin is degraded by the ozone breaking treatment. It is due to the high reactivity of ozone toward substances with conjugated double bonds or functional groups with high electronic density. Ozone attacks remarkably over lignin because of the presence of numerous double bonds.

The effects of the studied variables are reported in Figure 4 with reliability of $95 \%$. Nevertheless, at reliability of $90 \%$ it was proved that the moisture content, the waste type and the interaction between these two variables, affect the lignin concentration, but it does not affect reducing sugars. Therefore, the process favors itself for materials with high content of lignin and high moisture contents, since ozone is water-soluble and shows higher reactivity.

\subsection{Ultrasound and ozone combined pretreatment}

Taking into account the work reported by Guihua et al; (2010) [15], an experiment with its correspondent response was developed at the best operating conditions for each individual pretreatment. Because of the significance of the type of residual, it was decided to work with the rice hulls only, in order to process a waste with high content of lignin. The working conditions were: two hours for the ultrasound 


\section{Standardized Pareto Chart for reducing sugar}

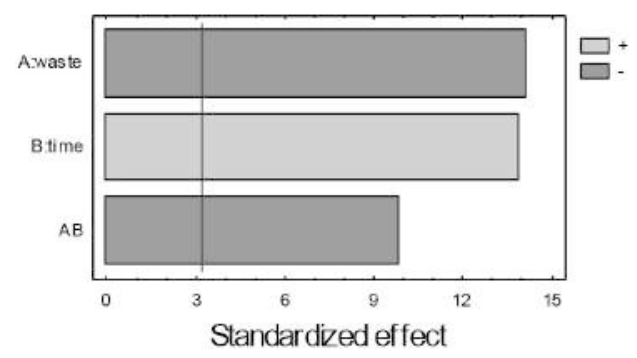

Standar dized Pareto Chart for reducing sugar

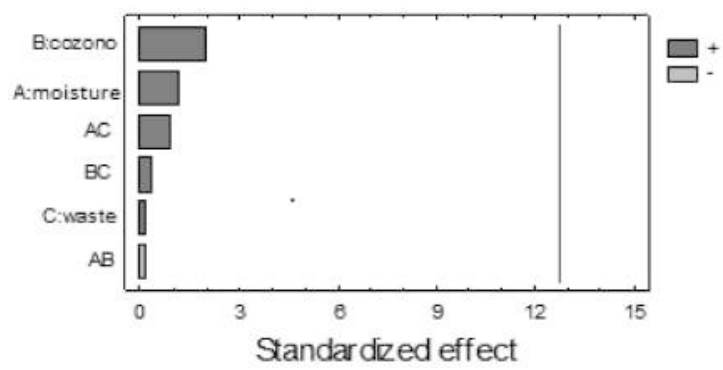

Standardized Pareto Chart for lignin

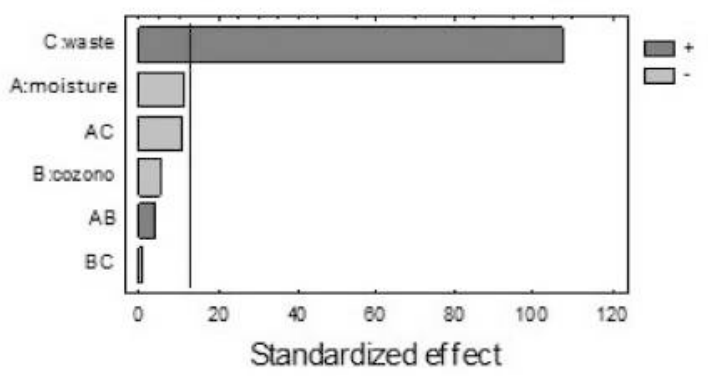

Figure 4 Effect of moisture, ozone concentration and type waste in ozonolysis

process and $30 \%$ of moisture content, ozone concentration of $20 \mathrm{mg} / \mathrm{L}$ for the ozone breaking process. The reported results are shown below (Table 5).

As it can be observed, concentration of reducing sugars increased regarding the untreated material (Table 2) and the concentration of lignin had an appreciable decrement when it is compared with each pretreatment separately. This behavior is completely favorable, because it is what it is looked for pretreatment to facilitate the attack of the enzymes in the later hydrolysis. Nevertheless, it is considered that the concentration of lignin still keeps high. Hence, it takes a deeper study to be able to take decisions.

\section{Standardized Pareto Chart for lignin}

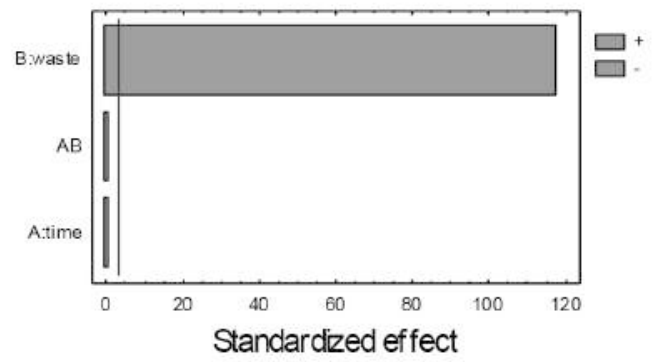

Figure 3 Effect of time and type waste in ultrasound pretreatment

Table 5 Results of combined pretreatment ( $\%$ in dry base weight)

\begin{tabular}{ccc}
\hline $\begin{array}{c}\text { Waste } \\
\text { a: replies }\end{array}$ & $\begin{array}{c}\text { Lignin } \\
(\%)\end{array}$ & $\begin{array}{c}\text { Reducing sugars } \\
\text { (mg/L) }\end{array}$ \\
\hline Rice hull & $15.760 \pm 0.012$ & $15.098 \pm 0.010$ \\
Rice hull & $15.561 \pm 0.015$ & $16.093 \pm 0.013$ \\
Rice hull & $13.172 \pm 0.015$ & $15.534 \pm 0.045$ \\
Rice hull & $14.988 \pm 0.011$ & $16.100 \pm 0.015$ \\
\hline
\end{tabular}

\subsection{Effect of ozone and ultrasound over lignocellulosic material structure}

In Figure 5, the SEM images are shown for both, non-processed and pre-processed lignocellulosic materials with ultrasound and ozone, but in this last with the initial content of humidity.

It can be observed that the structure of both pre-processed materials either by ultrasound or by ozone-breaking, suffers a transformation regarding the non-processed material. This can explain results in each pretreatment. In the case of the use of ozone with the higher moisture content $(30 \%)$, it is expected that the affectation of the structure for the rice hull is more sensitive because its higher content of lignin and higher reactivity.

The obtained results reflect the Gong - Yuan et al. (2009) study, where by means of the Scanning Electron Microscopy, the effect of the pretreatment with $\mathrm{H}_{2} \mathrm{SO}_{4}$ and $\mathrm{NaOH}$ on rice hull structure is analyzed [17].

\section{Conclusions}

The tobacco and rice wastes have differences in terms of lignocellulosic composition. This has an effect on the pretreatment to be applied. Within the range of studied variables with the ultrasound alternativefor reliability of $95 \%$, the results are not so clear. The type of residual, the moisture content and the interaction between both are the variables with significant influence, for reliability of 
rice hulls

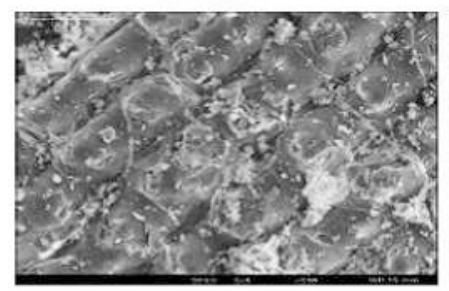

untreated wastes

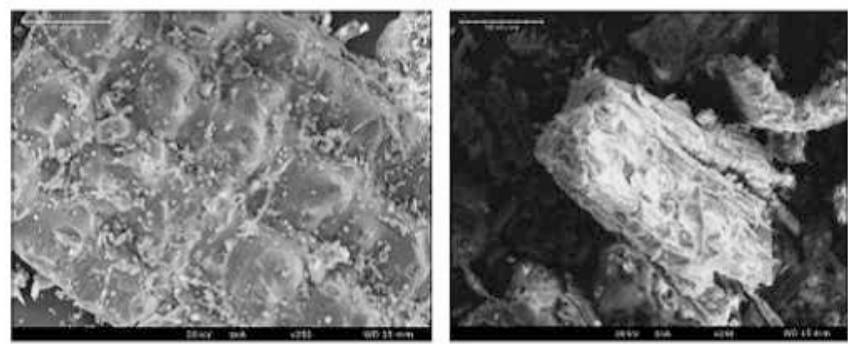

ultrasound

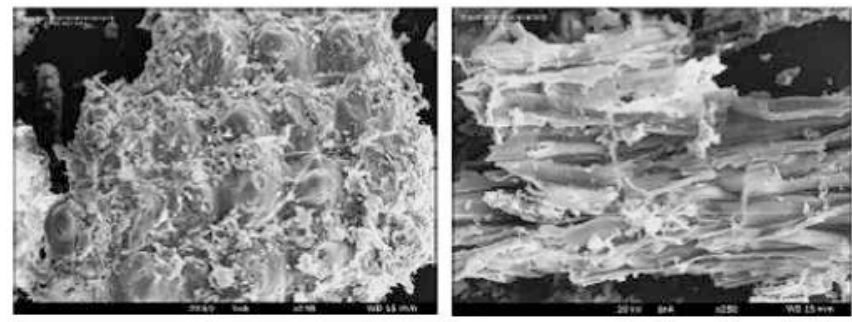

ozonolysis

Figure 5 Scanning electron microscopic (SEM) of material after process combination

$90 \%$ for the ozone alternative. For the studied conditions, the pretreatment with ozone is more effective to degrade the lignin than the ultrasound pretreatment. The best results of both pretreatments are obtained for the rice hull. The combined pretreatment showed higher degradation of lignin for the studied wasted (rice hulls), and it fixes with the structural transformation presented.

\section{References}

[1] Residuos de cosecha procesados, Manual de los derivados de la caña de azúcar, Instituto Cubano de Investigaciones de los Derivados de la Caña de Azúcar, La Habana, Cuba, 2000.
[2] M. J. Taherzadeh and K. Karimi, “Enzymatic-based hydrolysis processes for ethanol from lignocellulosic materials: a review," BioResources, vol. 2, no. 4, pp. 707-738, 2007.

[3] E. Cabrera, "Procedimiento versátil para el pretratamiento de residuos lignocelulósicos agroindustriales con vistasa la obtención de bioetanol," Ph.D. dissertation, Departamento de Tecnología de Alimentos, Universidad de Cádiz, Cádiz, España, 2013.

[4] M. W. Kuijpers, M. F. Kemmere, and J. T. Keurentjes, "Calorimetric study of the energy efficiency for ultrasound-induced radical formation," Ultrasonics, vol. 40, pp. 675-678, May 2002.

[5] M. Kunaver, E. Jasiukaityte, and N. Čuk, "Ultrasonically assisted liquefaction of lignocellulosic materials," Bioresource Technology, vol. 103, no. 1, pp. 360-366, Jan. 2012.

[6] A. A. Shatalov and H. Pereira, “Arundo donax L. reed: New perspectives for pulping and bleaching. 5. ozone-based tcf bleaching of organosolv pulps," Bioresource Technology, vol. 99, no. 3, pp. 472-478, Feb. 2008.

[7] A. Dufey and D. Stange, “Estudio regional sobre la economía de los biocombustibles en 2010: temas clave para los países de américa latina y el caribe," Estudio regional sobre la economía de los biocombustibles en 2010: temas clave para los países de América Latina y el Caribe, Santiago de Chile, Chile, Tech. Rep., Jun. 2011.

[8] A. Méndez, C. Robles, J. Ruiz, and E. Castañeda, “Compostaje de residuos agroindustriales inoculados con hongos lignocelulósicos y modificación de la relación 'C/N," Revista Mexicana De Ciencias Agrícolas, vol. 9, no. 2, pp. 271-280, 2018.

[9] D. Hyman and et al., "Determination of acid soluble lignin concentration curve by uv-vis spectroscopy," National Renewable Energy Laboratory, Golden, Colorado, Tech. Rep. NREL/TP-510-42617, Jan. 2008.

[10] A. Sluiter and et al., "Determination of structural carbohydrates and lignin in biomass," National Renewable Energy Laboratory, Golden, Colorado, Tech. Rep. NREL/TP-510-42618, Apr. 2008.

[11] A. Sluiter and et al., "Determination of ash in biomass," National Renewable Energy Laboratory, Golden, Colorado, Tech. Rep. NREL/TP-510-42622, Jan. 2008.

[12] G. L. Miller, "Use of dinitrosalicylic acid reagent for determination of reducing sugar," Anal. Chem., vol. 31, no. 3, pp. 426-428, 1959.

[13] C. Y. Yang, I. C. Sheih, and T. J. Fang, "Fermentation of rice hull by aspergillus japonicus under ultrasonic pretreatment," Ultrasonics Sonochemistry, vol. 19, no. 3, pp. 254-265, May 2012.

[14] M. T. García, G. González, I. Indacoechea, M. Coca, and S. Bolado, "Effect of ozonolysis pretreatment on enzymatic digestibility of wheat and rye straw," Bioresource Technology, vol. 100, no. 4, pp. 1608-1613, Feb. 2009.

[15] G. Xu, S. Chen, J. Shi, S.Wang, and G. Zhu, “Combination treatment of ultrasound and ozone for improving solubilization and anaerobic biodegradability of waste activated sludge," Journal of Hazardous Materials, vol. 180, no. 1-3, pp. 340-346, Aug. 2010.

[16] E. Estrada, "Pretratamiento ácido-alcalino de residuales tabacaleros para la obtención de bioetanol," Thesis, Instituto Superior Politécnico José Antonio Echeverría, La Habana, Cuba, 2011.

[17] W. Gong and et al., "Pretreatment and saccharification of rice hulls for the production of fermentable sugars," Biotechnology and Bioprocess Engineering, vol. 14, no. 6, pp. 828-834, Dec. 2009. 